\title{
Effect of intracerebroventricular infusion of genistein on prolactin and LH secretion in ovariectomized ewes during short days*
}

\author{
K. Romanowicz and T. Misztal ${ }^{1}$ \\ The Kielanowski Institute of Animal Physiology and Nutrition, \\ Polish Academy of Sciences \\ 05-110 Jabłonna, Poland
}

(Received 23 September 2004; revised version 15 December 2004; accepted 18 March 2005)

\begin{abstract}
This study was designed to test the hypothesis that genistein, a phytoestrogen, could immediately affect prolactin (PRL) and luteinizing hormone (LH) secretion in ovariectomized (OVX) ewes, when infused directly into the central nervous system (CNS) during short days. Starting 6 weeks after OVX, ewes were infused intracerebroventricularly (ICV) with a vehicle (control, $n=5$ ) or genistein $(10 \mu \mathrm{g} / 100 \mu \mathrm{l} / \mathrm{h}, \mathrm{n}=5)$. All infusions were performed from 12.00 to $16.00 \mathrm{~h}$ and blood samples were collected from 8.00 to $20.00 \mathrm{~h}$ at 10 -min intervals. The plasma PRL and LH concentrations were assayed by the radioimmunoassay methods. In vehicle-infused ewes, the mean plasma PRL concentration decreased significantly $(\mathrm{P}<0.05)$ during the infusion, compared with the pre-infusion $\mathrm{PRL}$ value. In genistein-infused ewes, a significant $(\mathrm{P}<0.001)$ increase in the PRL concentration was observed during the infusion, compared with the values noted before and after the treatment. The PRL concentration recorded during genistein infusion was also significantly $(\mathrm{P}<0.001)$ higher than the concomitant concentration in vehicle-infused animals. The mean plasma LH concentration in vehicle-infused ewes was significantly $(\mathrm{P}<0.01)$ higher after than both before and during the infusion. In genistein-infused ewes, the LH concentration measured after was significantly lower than both before $(\mathrm{P}<0.001)$ and during the infusion $(\mathrm{P}<0.01)$. Significant $(\mathrm{P}<0.01)$ differences also occurred between the concomitant LH concentrations recorded in vehicle- and genisteininfused groups. These results demonstrate that genistein may affect the hypothalamo-pituitary neuroendocrine axes activity in long-term OVX ewes, under the conditions of short days.
\end{abstract}

KEY WORDS: genistein, prolactin, LH, ovariectomy, intracerebroventricular infusion

\section{INTRODUCTION}

Genistein belongs to a family of phytoestrogens, which are found in many plants that are used in ruminant feeds (Adams, 1995). Although phytoestrogens

\footnotetext{
* Supported by the State Committee for Scientific Research, Grant No. 6 P06D 01120

${ }^{1}$ Corresponding author: e-mail: t.misztal@ifzz.pan.pl
} 
are partially metabolized by ruminal microorganisms after ingestion, they have been detected in constitutional fluids, i.e. blood plasma and milk, as well as in numerous animal tissues, including the reproductive organs and brain (Lundh et al., 1990; King et a., 1998). A variety of these compounds have been shown to effectively compete for $17 \beta$-estradiol (E2) binding to both isoforms of the oestrogen receptor (ER) $\alpha$ and $\beta$ (Kuiper et al., 1997). Interestingly, the oestrogenic potency of genistein has been found to be higher for ER $\beta$ than for ER $\alpha$.

E2 has been shown to be one of the most potent drugs stimulating PRL release. It is able to affect PRL directly at the pituitary lactotrophs by control of PRL gene expression and by modification of their sensitivity to physiological PRL secretion stimulators and inhibitors (Ben-Jonathan et al., 1989; Freeman et al., 2000). Within the hypothalamus, E2 modifies the activity of the neuroendocrine neurons known to control prolactin release (Ben-Jonathan et al., 1989; Freeman et al., 2000). The possible interactions of genistein with these mechanisms in ewes deserve investigation.

Changes in the feedback action of gonadal steroids on the hypothalamo-pituitary gonadotropic (GnRH-LH) axis determine the course of the ewe's reproductive cycle (Goodman et al., 1982). However, the effects of phytoestrogen biological activity in ewes were widely described as reproductive disturbances (Firth et al., 1977). Nwannenna et al. (1995) reported numerous clinically significant changes that occurred in the reproductive organs of ewes fed red clover. Changes in the size and colour of the vulva, uterus and udder, additionally in teat length and circumference, were similar to those observed during prolonged treatment with E2 (Nwannenna et al., 1995). Studies performed on rats and cows showed that ingestion of a diet containing phytoestrogens induced changes not only in reproductive organs but also reduced the frequency of the hypothalamic $\mathrm{GnRH}$ pulse generator and pituitary responsiveness to GnRH (Nwannenna et al., 1994; McGarvey et al., 2001). Until now no expression of classical ER has been found in ewe's GnRH neurons, which suggests that the hypothalamic neurotransmitter networks and/or glial cells are targets for oestrogenic compounds at the level of the CNS (Thiery et al., 2002).

Recent work has been shown that genistein, infused into the third ventricle of the brain, elicited marked increase in prolactin secretion and suppressed both the LH concentration and LH pulse frequency in OVX ewes kept under long-day conditions (Romanowicz et al., 2004). This indicated for a typical oestrogenic action of genistein in the CNS of ewe (Goodman et al., 1982; Ben-Jonathan et al., 1989; Freeman et al., 2000). Continuing our research, the current experiment was designed to examine the effects of genistein on PRL and LH secretion in OVX ewes during short-day conditions. 


\section{MATERIAL AND METHODS}

\section{Animals, management and experimental procedure}

The experiment was performed on 10 adult Polish Lowland ewes during a period of short days, from December to mid-January. They were maintained indoor under natural lighting conditions $\left(52^{\circ} \mathrm{N}, 21^{\circ} \mathrm{E}\right)$ and fed a constant diet of commercial concentrates, with hay and water available ad libitum. All ewes were ovariectomized 6 weeks before the experiment. The implantation of stainless steel guide canullae (1.2 mm o.d.) into the third ventricle was performed under stereotaxic control (Traczyk and Przekop, 1963), 3 weeks after OVX. The guide cannula was fixed to the skull with stainless steel screws and dental cement. The external opening to the canal was closed with a stainless steel cap. The placement of the guide cannula was confirmed by the outflow of a small amount of cerebrospinal fluid during surgery and after slaughtering by infusion of a small volume of blue ink.

Genistein (Sigma) was dissolved in ethanol and stored at $-20^{\circ} \mathrm{C}$ as a basic solution $(1 \mathrm{mg} / 500 \mu \mathrm{l})$ for no longer than 3 days. Immediately before the infusion, it was dissolved in saline. A similar solution, without genistein, was prepared for control infusion as a vehicle.

Three weeks after implantation of the canullae the ewes were divided into two groups and infused ICV with a vehicle (control, $\mathrm{n}=5$ ), or genistein, $10 \mu \mathrm{g} /$ $100 \mu \mathrm{l} / \mathrm{h}$ (total $40 \mu \mathrm{g}, \mathrm{n}=5$ ). The dose of genistein was selected according to our previous study (Romanowicz et al., 2004), in which it elicited significant changes in the secretion of the studied hormones in ewes kept under increasing day length conditions. All infusions were performed from 12.00 to $16.00 \mathrm{~h}$ and blood samples were collected from 8.00 to $20.00 \mathrm{~h}$, at 10 -min intervals through a catheter inserted into the jugular vein a day before the experiment. After centrifugation in heparinized tubes, plasma was stored at $-20^{\circ} \mathrm{C}$ until hormone assays were performed.

The ICV infusions were done with calibrated 1.0-ml gas-tight syringes and a CMA/100 microinjection pump. During the experiments the ewes were kept in comfortable cages where they could lie down and had unrestrained access to hay. The experimental procedures were approved by the Regional Ethics Committee, according to the Polish Guidelines for the Care and Use of Animals (1997).

\section{Analytical techniques}

The plasma concentration of prolactin was assayed by a radioimmunoassay (RIA) double-antibody method, using antiovine-PRL and antirabbit- 
gammaglobulin antiserum according to Wolińska et al. (1977). The assay sensitivity was $2 \mathrm{ng} / \mathrm{ml}$ and the intra- and interassay coefficients of variation were 9 and $12 \%$, respectively.

The plasma LH concentration was assayed by a RIA double-antibody method, using antiovine-LH and antirabbit-gammaglobulin antisera and bovine $\mathrm{LH}$ standard (NIH-LH-B6) according to Stupnicki and Madej (1976). The assay sensitivity was $0.3 \mathrm{ng} / \mathrm{ml}$, and the intra- and interassay coefficients of variation were 8.2 and $12.5 \%$, respectively.

\section{Statistical analysis}

Plasma PRL and LH concentrations are expressed as a mean \pm SEM. Due to the non-parametric nature of PRL secretion, the effects of the treatments on plasma PRL concentrations were analysed by the ANOVA rank Kruskal Wallis test (STATISTICA ${ }^{\mathrm{TM}}$ ). The same analysis was performed to determine the effects of the treatments on LH concentrations.

The frequency and amplitude of LH pulses were determined by the PCPULSAR computer program with $\mathrm{G}$ parameters: $\mathrm{G} 1=3.98, \mathrm{G} 2=2.40, \mathrm{G} 3=1.68$, $\mathrm{G} 4=1.24$ and $\mathrm{G} 5=0.93$. Analysis was performed individually for every ewe, and included the entire sampling period. The frequencies of LH pulses measured before, during and after the infusion were defined as the number of identified pulses per equal 4-h collecting periods and expressed as a mean \pm SEM. The significance of differences in the frequency and amplitude of LH pulses within (before, during and after the infusion) and between groups were assayed by the nonparametric ANOVA rank Kruskal-Wallis test.

\section{RESULTS}

\section{Prolactin}

In vehicle-infused ewes, the mean plasma PRL concentrations were: $48.9 \pm 6.6,33.8 \pm 3.8$ and $43.7 \pm 4.4 \mathrm{ng} / \mathrm{ml}$, before, during and after the infusion, respectively. The PRL concentration measured during vehicle infusion was significantly $(\mathrm{P}<0.05)$ lower than that before and did not differ statistically from the concentration noted after the infusion (Figure 1). 


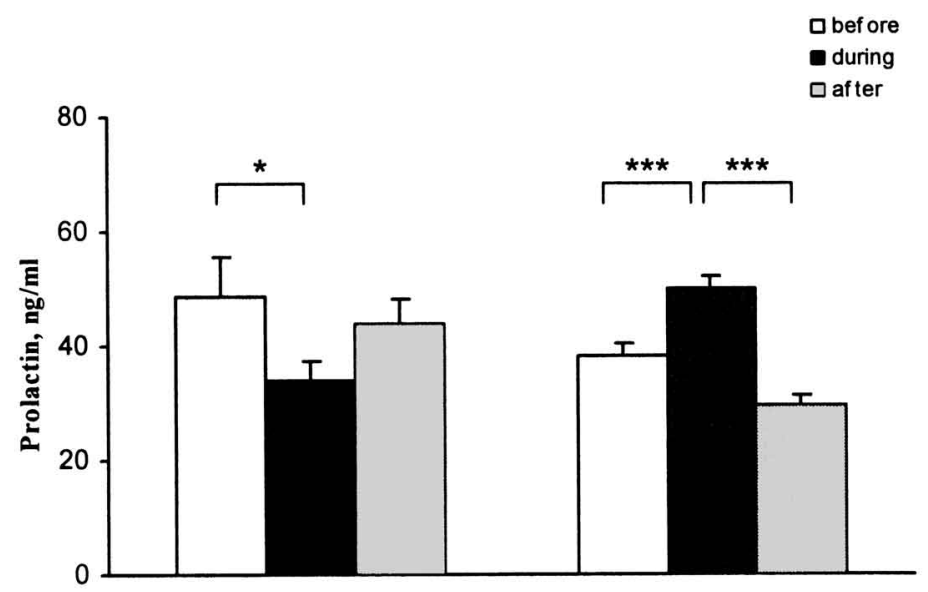

Figure 1. Mean $( \pm$ SEM) plasma prolactin concentrations in ovariectomized ewes before, during and after infusions of a vehicle ( $\mathrm{n}=5$, left panels) and genistein, $10 \mu \mathrm{g} / 100 \mu \mathrm{l} / \mathrm{h}(\mathrm{n}=5$, right panels), from 12.00 to 16.00 h. $\left({ }^{*} \mathrm{P}<0.05, * * * \mathrm{P}<0.001\right.$, see the text for additional statistical comparisons)

In genistein-infused ewes, the mean plasma PRL concentrations were: $38.1 \pm 2.3,50.0 \pm 2.2$ and $29.5 \pm 1.7 \mathrm{ng} / \mathrm{ml}$, before, during and after the infusion, respectively (Figure 1). The PRL concentration measured during genistein infusion was significantly $(\mathrm{P}<0.001)$ higher, compared with the values noted before and after the treatment. This concentration was also significantly $(\mathrm{P}<0.001)$ higher than the concomitant concentration in vehicle-infused animals. Examples of individual patterns of PRL secretion are shown in Figure 2.

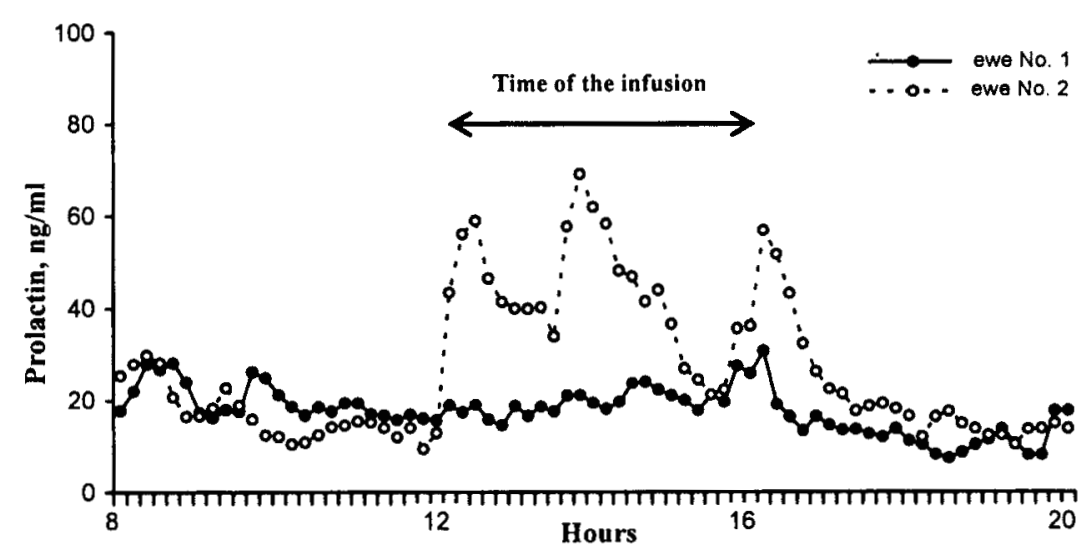

Figure 2. Effect of treatments on prolactin secretion in representative ewes infused intracerebrovent ricularly with vehicle (ewe No. 1) and genistein $(10 \mu \mathrm{g} / 100 \mu \mathrm{l} / \mathrm{h}$, ewe No. 6) from 12 to $16 \mathrm{~h}$ 


\section{$L H$}

In vehicle-infused ewes, the mean plasma LH concentrations were: $2.77 \pm 0.05,2.81 \pm 0.05$ and $3.26 \pm 0.06 \mathrm{ng} / \mathrm{ml}$, before, during and after the infusion, respectively (Figure 3). The LH concentration measured after vehicle infusion was significantly $(\mathrm{P}<0.01)$ higher than both before and during the infusion. Similarly, the frequency of LH pulses tended to increase after the infusion (data not shown).

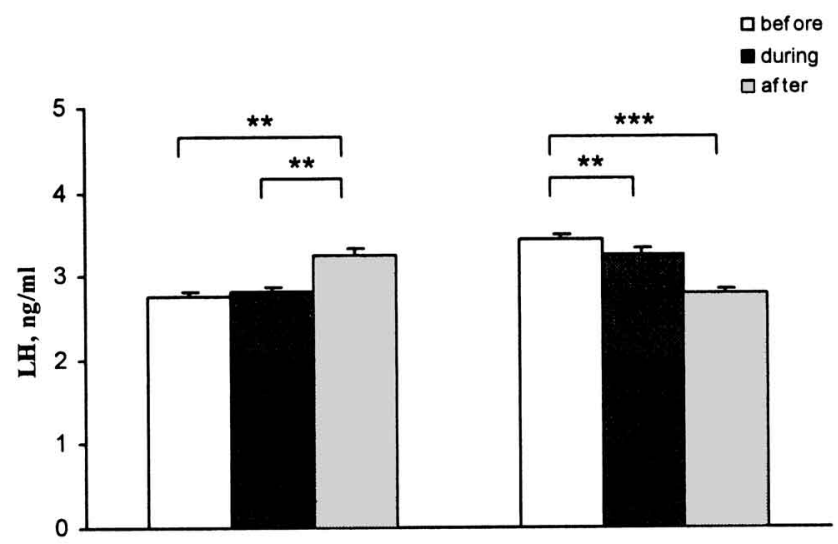

Figure 3. Mean $( \pm$ SEM) plasma LH concentrations in ovariectomized ewes before, during and after infusions of a vehicle ( $\mathrm{n}=5$, left panels) and genistein, $10 \mu \mathrm{g} / 100 \mu \mathrm{l} / \mathrm{h}(\mathrm{n}=5$, right panels), from 12.00 to $16.00 \mathrm{~h}$. $(* * \mathrm{P}<0.01, * * * \mathrm{P}<0.001$, see the text for additional statistical comparisons)

In genistein-infused ewes, the opposite direction of changes in LH secretion was observed: $3.45 \pm 0.06,3.24 \pm 0.08$ and $2.80 \pm 0.05 \mathrm{ng} / \mathrm{ml}$, before, during and after the infusion, respectively (Figure 3 ). The LH concentration noted after genistein infusion was significantly lower than both before $(\mathrm{P}<0.001)$ and during the infusion $(\mathrm{P}<0.01)$. Significant $(\mathrm{P}<0.01)$ differences also occurred between the concomitant concentrations recorded in vehicle- and genisteininfused groups. Importantly, the amplitude of LH pulses recorded after genistein infusion was significantly lower than that noted during it, $0.87 \pm 0.15$ vs $1.14 \pm 0.10 \mathrm{ng} / \mathrm{ml}(\mathrm{P}<0.01)$, respectively. Examples of individual patterns of LH secretion are shown in Figure 4. 


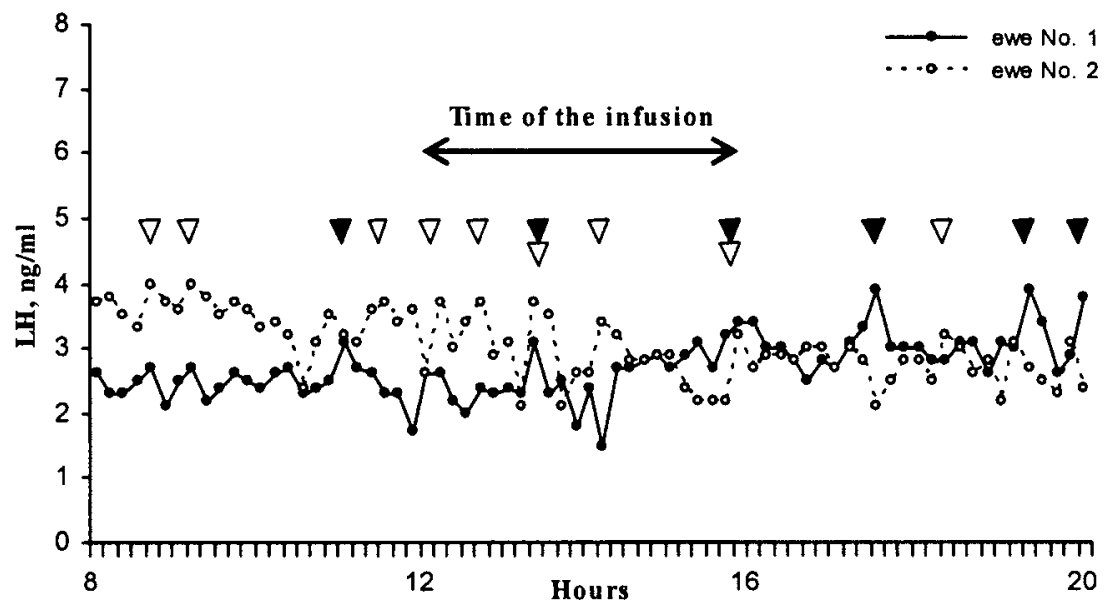

Figure 4. Effect of treatments on LH secretion in representative ewes infused intracerebroventric ularly with vehicle (ewe No. 2) and genistein $(10 \mu \mathrm{g} / 100 \mu \mathrm{l} / \mathrm{h}$, ewe No. 8) from 12 to $16 \mathrm{~h} ; \boldsymbol{\nabla} \nabla$, statistically significant pulses

\section{DISCUSSION}

The presented results demonstrate effective action of genistein on PRL secretion, following ICV infusion of this phytoestrogen in OVX ewes during short-day conditions, when natural plasma PRL level is minimal. Our findings are in agreement with others that have shown stimulation of PRL secretion by oestrogenic compounds in different animal species. For example, E2 stimulates the secretion, synthesis and storage of PRL as well as increases the size and number of pituitary lactotrophs (Ben-Jonathan et al., 1989). The most accepted mechanism for the central action of oestrogens is by affecting the dopaminergic system (BenJonathan et al., 1989; Freeman et al., 2000). Dopamine (DA) is recognized as a tonic inhibitor of PRL release whilst the major dopaminergic inputs involved in the control of PRL secretion in ewes originate from the A12 and A14 regions of the arcuate nucleus (Ben-Jonathan and Hnasko, 2001). E2 has been shown to inhibit numerous aspects of DA synthesis and release, but most of its effects were documented in rodents (Ben-Jonathan et al., 1989; Freeman et al., 2000). It was reported that in OVX rats, within $1 \mathrm{~h}$ of E2 treatment, tyrosine hydroxylase (TH) gene transcription in the arcuate nucleus was reduced to $5 \%$ of control (Blum et al., 1987). The nongenomic action of oestrogen on the membrane-associated second messenger signalling system was suggested, in turn, by Pasqualini et al. (1993), who showed a short-term inhibitory effect of oestrogen on TH activity 
using hypothalamic slices. An immediate response of PRL to genistein infusion observed here in ewes suggests that a similar mechanism would mediate its action. Our recent findings in OVX ewes treated ICV with genistein during a period of long days have shown dose-dependent stimulation of PRL secretion by this phytoestrogen (Romanowicz et al., 2004). Moreover, the use of the same dose in those ewes elicited a much higher increase in PRL secretion, lasting in some individuals up to the end of the experiment (Romanowicz et al., 2004). This in turn suggests a different seasonal sensitivity of ewes' hypothalamic DA system to oestrogens, especially following the long-term ovariectomy. Similar stimulation of PRL was obtained in OVX ewes after an intravenous infusion of E2 (Rozell and Keisler, 1990). Interestingly, the serum concentration of PRL reached maximum levels, while the concentration of phytoestrogen in the brain continued to increase during the infusion. This is, therefore, in agreement with the suggestion that the concentration of oestrogens must increase to stimulate secretion of PRL in ewes (Rozell and Keisler, 1990). In contrast to that, some spontaneous enhancements in PRL levels noted during the initial phase of sampling in all animal groups might result from the handling involved in the preparation for the experiment.

A distinct daily pattern of LH secretion was shown in our control animals, with an increasing concentration during the evening hours. A similar rhythm in LH secretion was also described earlier in ewes (Misztal et al., 2002). On the contrary, infusion of genistein, directly into the third ventricle of the brain, elicited immediate suppression of LH secretion. It was reflected by a decrease in either the LH concentration or LH pulse amplitude after genistein infusion. Unexpectedly, the level of LH in some individuals of experimental group was higher than in control ewes, but it does not rule out the effect of the drug seen within this group, which differed from the control. It is reasonable to mention here our previous work on OVX ewes during the long days, where both the LH concentration and LH pulse frequency decreased significantly after ICV infusion of genistein (Romanowicz et al., 2004). Taken together, our results show an oestrogenic, related to a season, effect of genistein on the GnRH-LH axis in ewes, since during short days (breeding season) oestrogens inhibit LH pulse amplitude, but during long days (anoestrus) markedly suppress pulse frequency (Goodman et al., 1982). They also confirm the hypothesis that phytoestrogens may interfere with the normal oestrogen feedback mechanism involved in the release of gonadotropins (Mathieson and Kitts, 1980).

The changes in LH secretion following genistein administration are similar to those observed by others after treatment with E2. Caraty et al. (1989) demonstrated that a single administration of E2 induces a biphasic response in the secretion of this gonadotropin in OVX ewes with a negative feedback appearing during the initial phase. In the study of Gallegos-Sanchez et al. (1996), E2 required more 
than $8 \mathrm{~h}$ and less than $18 \mathrm{~h}$ to initiate a statistically significant decrease in the frequency of LH pulses in OVX ewes. However, the cited authors observed a decrease in LH secretion in a few individuals within 4 to $8 \mathrm{~h}$ of E2 treatment. According to Caraty et al. (1989), a rapid decrease in LH secretion immediately after oestrogen administration is caused by a reduction in both frequency and amplitude of GnRH pulses, suggesting that oestrogen exerts feedback at the level of the hypothalamus. Thus, the presented action of genistein could be exerted principally on the hypothalamic structures that control GnRH release via neurotransmitters produced by them, since until now no expression of ER has been found in ewe's GnRH neurons. On the other hand, genistein was also shown to be a potent non-specific protein tyrosine kinase inhibitor (Dixon and Ferreira, 2002), thus its action within the GnRH neurons and/or the pituitary gonadotrophs cannot be excluded and deserves further investigation.

Phytoestrogens may be extensively metabolized and biotransformed by the rumen microflora (Adams, 1995). The oestrogenic isoflavones like genistein and biochanin-A may be broken down to the non-oestrogenic 4-ethyl-phenol and organic acids (Anderson et al., 1999). Ruminal microorganisms may take, however, 6 to 10 days to adapt fully to these substrates, so genistein may produce oestrogenic effects in sheep during the first few days after introduction of the phytoestrogenic diet. Lundh et al. (1990) demonstrated that the total amounts of the plant oestrogens and their metabolites in ovine blood plasma increased successively and reached the maximum level after about $3 \mathrm{~h}$ of intake. The dose of genistein, used for the ICV infusion in our experiment, probably does not mimic the concentration of phytoestrogen, which occur within the brain after ingestion of oestrogenic feeds, however, its pharmacological effects on PRL and LH secretion in ewes are similar to these described for E2 (cited above).

Summarizing, the presented results are successive evidence that genistein is an effective modulator of PRL and LH secretion in OVX ewes by acting directly on the CNS. Some reproductive disturbances, caused by phytoestrogens, may therefore have a base in the dysfunction of the hypothalamo-pituitary GnRH-LH axis.

\section{ACKNOWLEDGEMENTS}

We wish to thank Józef Rutkowski for help in brain surgery and the other members of the Department of Endocrinology for technical assistance with the radioimmunoassays. 


\section{EFFECT OF GENISTEIN ON PROLACTIN AND LH SECRETION IN EWES}

\section{REFERENCES}

Adams R.N., 1995. Detection of the effects of phytoestrogens on sheep and cattle. J. Anim. Sci. 73, $1509-1515$

Anderson J.J.B., Anthony M., Messina M., Garner S.C., 1999. Effects of phyto-oestrogens on tissues. Nutr. Res. Rev. 12, 75-116

Ben-Jonathan N., Arbogast L.A., Hyde J.F., 1989. Neuroendocrine regulation of prolactin release. Prog. Neurobiol. 33, 399-447

Ben-Jonathan N., Hnasko R., 2001. Dopamine as a prolactin (PRL) inhibitor. Endocrine Rev. 22, 724-763

Blum M., McEven B.S., Roberts J.L., 1987. Transcriptional analysis of tyrosine hydroxylase gene expression in the tuberoinfundibular dopaminergic neurons of the rat arcuate nucleus after estrogen treatment. J. Biol. Chem. 262, 817-821

Caraty A., Locatelli A., Martin G.B., 1989. Biphasic response in the secretion of gonadotrophinreleasing hormone in ovariectomized ewes injected with oestradiol. J. Endocrinol. 123, 375382

Dixon R.A., Ferreira D., 2002. Genistein. Phytochemistry 60, 205-211

Firth J.F., Salamon S., Maxwell W.M.C., 1977. Observations on oestrus without ovulation in sheep. Theriogenology 8, 186-190

Freeman M.E., Kanyicska B., Lerant A., Nagy G., 2000. Prolactin: structure, function and regulation of secretion. Physiol. Rev. 80, 1523-1631

Gallegos-Sanchez J., Picard S., Delaleu B., Malpaux B., 1996. Initiation of the oestradiol-induced inhibition of pulsatile LH secretion in ewes under long days: comparison of peripheral versus central treatment and neurochemical correlates. J. Endocrinol. 151, 19-28

Goodman R.L., Bittman E.L., Foster D.L., Karsch F.J., 1982. Alterations in the control of luteinizing hormone pulse frequency underline the seasonal variation in estradiol negative feedback in the ewe. Biol. Reprod. 27, 580-589

King R.A., Mano M.M., Head R.J., 1998. Assessment of isoflavonoid concentrations in Australian bovine milk samples. J. Dairy Res. 65, 479-489

Kuiper G.G.J.M., Carlsson B., Grandien K., Enmark E., Haggbland J., Nilsson S., Gustfsson J.A., 1997. Comparison of the ligand binding specificity and transcript tissue distribution of estrogen receptors $\alpha$ and $\beta$. Endocrinology 138, 863-870

Lundh T.J.O., Pettersson H.I., Martinsson K.A., 1990. Comparative levels of free and conjugated plant estrogens in blood plasma of sheep and cattle fed estrogenic silage. J. Agr. Food Chem. $38,1530-1534$

Mathieson R.A., Kitts W.D., 1980. Binding of phyto-estrogen and oestradiol-17 $\beta$ by cytoplasmic receptors in the pituitary gland and hypothalamus of the ewe. J. Endocrinol. 85, 317-325

McGarvey C., Cates P.S., Brooks A.N., Swanson I.A., Milligen S.R., Coen C.W., O'Byrne K.T., 2001. Phytoestrogens and GnRH pulse generator activity and pituitary LH release in the rat. Endocrinology 142, 1202-1208

Misztal T., Romanowicz K., Barcikowski B., 2002. Effect of melatonin on daily LH secretion in intact and ovariectomized ewes during the breeding season. Anim. Reprod. Sci. 69, 187-198

Nwannenna A., Lundh T.J.-O., Madej A., Fredriksson G., Bjornhag G., 1995. Clinical changes in ovariectomized ewes exposed to phytoestrogens and oestradiol-17 $\beta$ implants. Proc. Soc. Exp. Biol. Med. 208, 92-97

Nwannenna A., Madej A., Lundh T.J-O, Fredriksson G., 1994. Effects of oestrogenic silage on some clinical and endocrinological parameters in ovariectomized heifers. Acta Vet. Scand. 35, $173-$ 183 
Pasqualini C., Guibert B., Leviel V., 1993. Short-term inhibitory effect of estradiol on tyrosine hydroxylase activity in tuberoinfundibular dopaminergic neurons in vitro. J. Neurochem. 60, $1707-1713$

Romanowicz K., Misztal T., Barcikowski B., 2004. Genistein, a phytoestrogen, effectively modulates luteinizing hormone and prolactin secretion in ovariectomized ewes during seasonal anestrus. Neuroendocrinology 79, 73-81

Rozell T.G., Keisler D.H., 1990. Effects of oestradiol on LH, FSH and prolactin in ovariectomized ewes. J. Reprod. Fertil. 88, 645-653

Stupnicki R., Madej A., 1976. Radioimmunoassay of LH in blood plasma of farm animals. Endokrinologie 68, 6-13

Thiery J.C., Chemineau P., Hernandez X., Migaud M., Malpaux B., 2002. Neuroendocrine interactions and seasonality. Domest. Anim. Endocrinol. 23, 87-100

Traczyk W., Przekop F., 1963. Methods of investigation of the function of the hypothalamus and hypophysis in chronic experiments in sheep. Acta Physiol. Pol. 14, 217-226

Wolińska E., Polkowska J., Domański E., 1977. The hypothalamic centers involved in the control of production and release of prolactin in sheep. J. Endocrinol. 73, 21-29

\section{STRESZCZENIE}

\section{Wpływ genisteiny, infundowanej dokomorowo, na sekrecję prolaktyny i LH u owariektomizo- wanych owiec w warunkach krótkiego dnia}

Celem badań było określenie wpływu fitoestrogenu, genisteiny, infundowanego do trzeciej komory mózgowej na sekrecję prolaktyny (PRL) i hormonu luteinizującego (LH) u owiec owariektomizowanych, w okresie krótkiego dnia. Infuzje kontrolne $(\mathrm{n}=5)$ i genisteiny $(10 \mu \mathrm{g} / 100$ $\mu \mathrm{l} / \mathrm{h}, \mathrm{n}=5$ ) wykonywano w 6 tygodni po owariektomii, od godz. 12.00 do 16.00 . W próbkach krwi, pobieranych co $10 \mathrm{~min}$, od godz. 8.00 do 20.00, oznaczano stężenia PRL i LH metodą radioimmunologiczną. $U$ owiec kontrolnych średnie stężenie PRL w czasie infuzji było istotnie $(\mathrm{P}<0,05)$ niższe od stężenia przed- i nie różniło się istotnie od stężenia po infuzji. Genisteina infundowana dokomorowo spowodowała istotny $(\mathrm{P}<0,001)$ wzrost stężenia PRL w porównaniu z wartościami przed i po infuzji. Stężenie PRL w czasie infuzji genisteiny było również istotnie $(\mathrm{P}<0,001)$ wyższe od stężenia w czasie infuzji kontrolnej. Średnie stężenie LH u owiec kontrolnych było istotnie $(\mathrm{P}<0,01)$ wyższe po infuzji niż przed i w czasie infuzji. U owiec, u których wykonano infuzje genisteiny, stężenie LH było istotnie niższe po infuzji niż stężenia przed $(\mathrm{P}<0,001)$ i w czasie infuzji $(\mathrm{P}<0,01)$. Stwierdzono także istotne $(\mathrm{P}<0,01)$ obniżenie amplitudy pulsów LH u owiec po infuzji genisteiny. Przedstawione wyniki wskazują, że fitoestrogen, genisteina, może modulować neuroendokrynną aktywność podwzgórza i przysadki u owiec owariektomizowanych, w warunkach krótkiego dnia. 